\title{
Interspecific interactions drive chitin and cellulose degradation by aquatic microorganisms
}

\author{
Gianluca Corno ${ }^{1, *}$, Ivette Salka ${ }^{2}$, Kirsten Pohlmann ${ }^{2}$, Alex R. Hall ${ }^{3}$, \\ Hans-Peter Grossart ${ }^{2,4}$ \\ ${ }^{1}$ CNR-Institute of Ecosystem Study, Largo Tonolli 50, 28922 Verbania, Italy \\ ${ }^{2}$ Leibniz-Institute of Freshwater Ecology and Inland Fisheries (IGB), Alte Fischerhuette 2, 16775 Stechlin, Germany \\ ${ }^{3}$ Institute of Integrative Biology, ETH Zürich, 8092 Zürich, Switzerland \\ ${ }^{4}$ Institute of Biochemistry and Biology, Potsdam University, Am neuen Palais 10, 14469 Potsdam, Germany
}

\begin{abstract}
Complex biopolymers (BPs) such as chitin and cellulose provide the majority of organic carbon in aquatic ecosystems, but the mechanisms by which communities of bacteria in natural systems exploit them are unclear. Previous degradation experiments in artificial systems predominantly used microcosms containing a single bacterial species, neglecting effects of interspecific interactions. By constructing simplified aquatic microbial communities, we tested how the addition of other bacterial species, of a nanoflagellate protist capable of consuming bacteria, or of both, affect utilization of BPs. Surprisingly, total abundance of resident bacteria in mixed communities increased upon addition of the protist. Concomitantly, bacteria shifted from free-living to aggregated morphotypes that seemed to promote utilization of BPs. In our model system, these interactions significantly increased productivity in terms of overall bacterial numbers and carbon transfer efficiency. This indicates that interactions on microbial aggregates may be crucial for chitin and cellulose degradation. We therefore suggest that interspecific microbial interactions must be considered when attempting to model the turnover of the vast pool of complex biopolymers in aquatic ecosystems.
\end{abstract}

KEY WORDS: Aggregation - Flagellate grazing - Ecological interactions - Microbial carbon transfer $\cdot$ Polymer degradation $\cdot$ System ecology

\section{INTRODUCTION}

Bacterial mineralization and uptake of organic matter (OM) represent fundamental steps in carbon (C) cycling in aquatic ecosystems. OM quantity and quality can both affect bacterial community composition and substrate utilization (Sinsabaugh \& Findlay 2003), implying that different bacterial species vary in their capacity to exploit stored C, and in turn that bacterial community composition may itself influence the efficiency of OM processing (del Giorgio et al. 2011). While labile compounds such as amino acids are readily available for most bacteria, the decomposition of polymeric OM, such as chitin and cellulose, requires specialized pathways, usually controlled by complex regulation processes and interactions (del Giorgio \& Newell 2012). Thus, it is assumed that only a specific fraction of natural bacterial communities can access the vast pool of organic polymers. Consistent with this, in many freshwater ecosystems, estuaries and coastal areas (representing the most productive systems and up to $20 \%$ of the surface waters on earth, and where most of the OM is directly accessible to only a very limited number of highly specialized bacteria) there appears to be a direct link between OM quality and bacterial community composition (Hutalle-Schmelzer et al. 2010). Bacteria in such communities frequently form syntrophic associations and/or co-metabolism with other species (McInerney et al. 2008), indicating that inter- 
specific interactions impact the functioning of the entire ecosystem (Keller \& Surette 2006). Consequently, changing community composition due to, for example, invasion by allochthonous organisms following climate change or flooding may cause important changes in system efficiency (Venail et al. 2008, Horňák \& Corno 2012). Indeed, recent studies (e.g. Litchman 2010, Hahn et al. 2012) have suggested that microbial interactions are central to improving our understanding of polymeric organic matter degradation by natural microbial communities.

For example, predation of bacteria by protozoa can cause huge changes in bacterial community structure in waters, both by direct selection of the prey and by indirect release of dissolved labile $\mathrm{C}$ as exudate during the process of digestion of the captured prey. The concomitant direct and indirect effects of grazing on bacterial communities have been observed in large temperate lakes (Corno et al. 2008), in high mountains lakes (Callieri et al. 2006), and tested in laboratory-based experimental systems (Corno \& Jürgens 2008). Indeed, even without protozoan grazing of bacteria, energy transfer and OM cycling will depend on interspecific interactions (Jiao et al. 2010, Nobu et al. 2015). For example, more diverse communities tend to lead to higher C-utilization efficiencies (Miki et al. 2014). Therefore, interspecific interactions that influence community composition, such as invasion by a single competitively dominant species, may influence community-level C-transfer efficiency.

The present study investigates the ecological interactions between microorganisms in simplified multispecies communities (Jessup et al. 2005), testing whether interactions among bacterial species and between bacteria and protozoan grazers influence community assembly and degradation of complex $\mathrm{C}$ polymers. We designed a bacterial model community of 4 freshwater species with different physiological behaviors and growth rates when grown on chitin or cellulose as the sole C-source. We selected chitin and cellulose as they represent two of the most abundant biopolymers on earth, particularly in aquatic ecosystems, with huge production rates at a global level (Gooday 1990). Furthermore, their decomposition is not a simple process, but there is no evidence of longterm accumulation of those substrates in aquatic ecosystems (Gooday 1990). This suggests complex and efficient degradation pathways involving a number of interactions (Mayor et al. 2014), as demonstrated in decomposing wood (Borsodi et al. 2005), sediments (Cardenas et al. 2008), wetlands (Ibekwe et al. 2003), and bioreactors (Hiibel et al. 2008).
In order to raise the number of potential interactions, we tested for the effect of a protist (Poterioochromonas, known to graze bacterial cells under a wide range of conditions; Callieri et al. 2006, Corno 2006, Blom \& Pernthaler 2010), on bacterial community composition and degradation of biopolymers (chitin and cellulose). We also tested community-level responses to the introduction of an additional bacterial species that we expected to be competitively dominant under these conditions: Burkholderia, common in conditions with abundant polymeric OM (Hutalle-Schmelzer et al. 2010) and potentially able to express chitino- (Kong et al. 2001) and cellulolytic activity (Liang et al. 2014). We found that community-level responses to predation differed from those of individual species, and that introduction of a protozoan grazer can enhance bacterial degradation of both chitin and cellulose by inducing bacterial co-aggregation.

\section{MATERIALS AND METHODS}

\section{Organisms}

Flectobacillus sp. strain GC009 (Bacteroidetes, hereafter referred to as Flectobacillus) was isolated from an enrichment culture of mesotrophic Lake Schoehsee, Germany. Arthrobacter agilis strain GC027, Brevundimonas sp. strain GC044, and Aeromonas hydrophila strain GC015 were isolated from an enrichment culture of Lake Zürich, Switzerland. Partial 16S rRNA sequences of our A. agilis, Brevundimonas, and A. hydrophila strains were deposited in GenBank under accession numbers JN009621, JN009622, and KJ409640, respectively. Burkholderia sp. strain AH62 was introduced into some of the microcosms after $3 \mathrm{~d}$ of preconditioning the resident bacterial community to the respective substrates (see below). We selected Poterioochromonas sp. strain DS (hereafter referred to as Poterioochromonas or 'Protist') as a bacterial grazer because it is common in freshwater, where it is one of the most efficient interception feeding predators (Rothhaupt 1997). Further details of the organisms used are given in the Supplement at www.int-res.com/ articles/suppl/a076p027_supp.pdf.

\section{Experimental setup}

The experimental design consisted of replicate microcosms, each containing a community of 4 bacterial species grown in the dark at $20^{\circ} \mathrm{C}$ in inorganic artifi- 
cial lake water (ALW) medium (Zotina et al. 2003) enriched with chitin or cellulose $\left(27 \mathrm{mg} \mathrm{l}^{-1}\right)$ as the sole $\mathrm{C}$ source (final concentration of $\mathrm{C}=9 \mathrm{mg} \mathrm{l}^{-1}$ ). Prior to inoculation, bacteria were preconditioned for $3 \mathrm{~d}$ under the same conditions as in the main experiment. We grew such communities in 4 treatments: 'Control', with these 4 species only; 'Burkholderia', where we introduced an additional bacterial species expected to be competitively dominant under these conditions and therefore to act as an invasive species; 'Protist', where we introduced a protozoan grazer expected to act as a predator of bacteria; and 'Burkholderia+Protist', with both together. Prior to inoculation, Burkholderia was cultivated under the same conditions as all other bacteria, but in DEV Lactose Peptone Broth. In each treatment, we measured productivity, diversity and $\mathrm{C}$ transfer efficiency of the community.

Additionally, we grew the protist and Burkholderia both alone and in the presence of each individual bacterial species, to determine whether they could exploit those biopolymers in the absence of the mixed bacterial community. We also grew each bacterial species on its own in all 4 treatments to determine whether responses to Burkholderia or protists were specific to multi-species communities.

For each microcosm, the 4 preconditioned bacterial species were inoculated into $500 \mathrm{ml}$ ALW in a $1000 \mathrm{ml}$ Erlenmeyer flask, resulting in an initial total cell abundance of $\sim 4.5 \times 10^{4} \mathrm{cells} \mathrm{ml}^{-1}$. The same concentration was used to inoculate single-species controls, which were grown in triplicate on both C sources separately for $11 \mathrm{~d}$ in the dark at $20^{\circ} \mathrm{C}$. Mixed communities were grown in triplicate on both $\mathrm{C}$ sources at $20^{\circ} \mathrm{C}$ in the dark. On Day 3, each replicate community was divided into two $250 \mathrm{ml}$ sub-treatments, to one of which we added Burkholderia (at 1:100 Burkholderia:resident bacteria). On Day 5, each community incubation was again divided into two $125 \mathrm{ml}$ sub-treatments, one receiving the protist Poterioochromonas (at 1:1000 protist:resident bacteria). At each division step the size of the Erlenmeyer flask was reduced accordingly, in order to maintain a constant volume:surface ratio (between 2.2 and 2.4) in the different treatments for the whole experiment. Samples for total cell counts and morphological analysis of resident bacteria in mixed control communities were taken on Days $0,3,5,6,8,9,10$, and 11, whereas Burkholderia and Protist treatments were sampled from their creation onwards (Days 3 and 5, respectively). Subsamples $(10 \mathrm{ml})$ for catalyzed reporter deposition-fluorescence in situ hybridization (CARDFISH) were taken on Days 3, 5, and 11, to estimate the relative abundances of different bacterial species.

\section{Cell counts and determination of dissolved organic carbon/total organic carbon}

Overall bacterial and protist cell numbers were counted using a FACSAria II flow cytometer (Becton Dickinson) according to the protocol of Gasol et al. (1999). To confirm flow-cytometric counts, bacterial and protist numbers were additionally assessed by epifluorescence microscopy using a Zeiss Axio Imager 1 and 1000× magnification for every fourth sample (results correspondence always $>95 \%$, data not shown). Bacterial community composition analyzed by CARD-FISH and total (TOC) as well as dissolved organic carbon (DOC) were determined at Days 3, 5, and 11 (full protocols are provided in the Supplement).

\section{Aggregate features and $\mathrm{C}$ transfer}

Aggregate size was estimated by determining the maximal Feret dimension (the largest possible diameter fitting within the aggregate, $\mathrm{Fe}_{\max }$ ) of each aggregate detected on DAPI and CARD-FISH stained filters (specific probes for each strain were used, as explained in detail in the Supplement). Aggregates were grouped into size classes using a $10 \mu \mathrm{m}$ step width. Cell clusters composed of a single strain and with $\mathrm{Fe}_{\max }<10 \mu \mathrm{m}$ were termed microcolonies (Corno et al. 2013). Volumes and organic C content of bacteria and flagellate cells were estimated according to Loferer-Krössbacher et al. (1998) and Menden-Deuer et al. (2001); the amount of C utilized by predators after ingestion of the bacterial prey was considered as $43 \%$ of the overall prey C content for Poterioochromonas (ingested prey biomass $=$ estimated protist biomass gain $\times 0.43$ ). The overall amount of $\mathrm{C}$ for each group of organisms was obtained by multiplying the amount of $\mathrm{C}$ estimated per cell for the number of cells of the group. The amount of $\mathrm{C}$ excreted by predators was estimated as $35 \%$ of the ingested $\mathrm{C}$ and considered as labile DOC (Pelegrí et al. 1999).

\section{Statistical analyses}

We first tested whether bacterial growth differed between cellulose and chitin media by taking the average total bacterial abundance over time in each replicate, then using Welch's $t$-test for an average difference between chitin and cellulose in the Control treatments. By using mixed linear models for 
comparing different treatments (Protist, Burkholderia, Burkholderia+Protist or Control), we accounted for the non-independence within replicates in the same as well as in different treatments, by averaging over time and including replicate within chitin or cellulose media as a random effect ('Ime4' package in $\mathrm{R}_{\text {; }}$ R Development Core Team 2013). We fitted models by maximum likelihood and tested the significance of fixed effects (treatment and growth medium) by likelihood ratio tests comparing full and reduced models (Crawley 2007). In some cases we compared each treatment pairwise to the Control; in such cases we accounted for multiple testing by only accepting statistical significance when $\mathrm{p}<\alpha$, with $\alpha$ adjusted by sequential Bonferroni correction. Bacterial abundances were log-transformed to improve the linear fit; this did not qualitatively affect results. We used the same approach to analyze the fraction of bacterial cells in aggregates at the end of the experiment, arcsine-transforming proportion data prior to analysis.

\section{RESULTS}

\section{Bacterial growth on chitin and cellulose with and without Protist and Burkholderia}

Growth of bacteria in pure cultures varied among species and depending on $\mathrm{C}$ source (cellulose or chitin; Fig. 1). After 3 d, Aeromonas hydrophila grew to $\sim 0.5 \times 10^{6}$ cells $\mathrm{ml}^{-1}$ on chitin, but then rapidly decreased to $\sim 0.15 \times 10^{6}$ cells ml ${ }^{-1}$, comparable to the same species on cellulose. Brevundimonas grew well on chitin, reaching $\sim 10^{6}$ cells ml ${ }^{-1}$ after $3 \mathrm{~d}$ before slowly declining until Day 11 . This species was less successful on cellulose, but still formed distinct populations, with $\sim 0.3 \times 10^{6}$ cells ml ${ }^{-1}$ after $3 \mathrm{~d}$ and decreasing thereafter. Arthrobacter agilis and especially Flectobacillus did not grow well on either $\mathrm{C}$ source (Fig. 1). By contrast, Burkholderia, predicted to be well-adapted to these conditions, grew steadily in pure culture, reaching its highest abundances at the final time point on both chitin $\left(0.39 \times 10^{6}\right.$ cells $\left.\mathrm{ml}^{-1}\right)$ and cellulose $\left(0.17 \times 10^{6} \mathrm{cells} \mathrm{ml}^{-1}\right)$.

The 4 -species bacterial community grown in the absence of Burkholderia or the protist reached higher average cell numbers on chitin than on cellulose (Welch's $t_{3.11}=15.44, \mathrm{p}<0.001 ;$ ' $\mathrm{C}$ ' in Fig. 2 ). $A$. hydrophila and Brevundimonas were the most abundant species in control communities grown on both carbon sources (Fig. 3). By comparing bacterial abundances in pure and mixed cultures, we inferred that interspecific competitive interactions were relatively strong in chitin cultures, as shown by relatively low population densities in mixed cultures compared to a null model based on growth in pure cultures (Fig. S1 in the Supplement at www.int-res.com/articles/ suppl/a076p027_supp.pdf).

Total bacterial abundance at the end of the experiment varied among our experimental treatments $\left(\chi^{2}=53.77, \mathrm{df}=3, \mathrm{p}<0.0001 ;\right.$ Fig. 2). Addition of Poterioochromonas (' $\mathrm{P}$ ' in Fig. 2) caused significant changes in bacterial growth, with abundance of the resident bacteria rapidly increasing after the protist
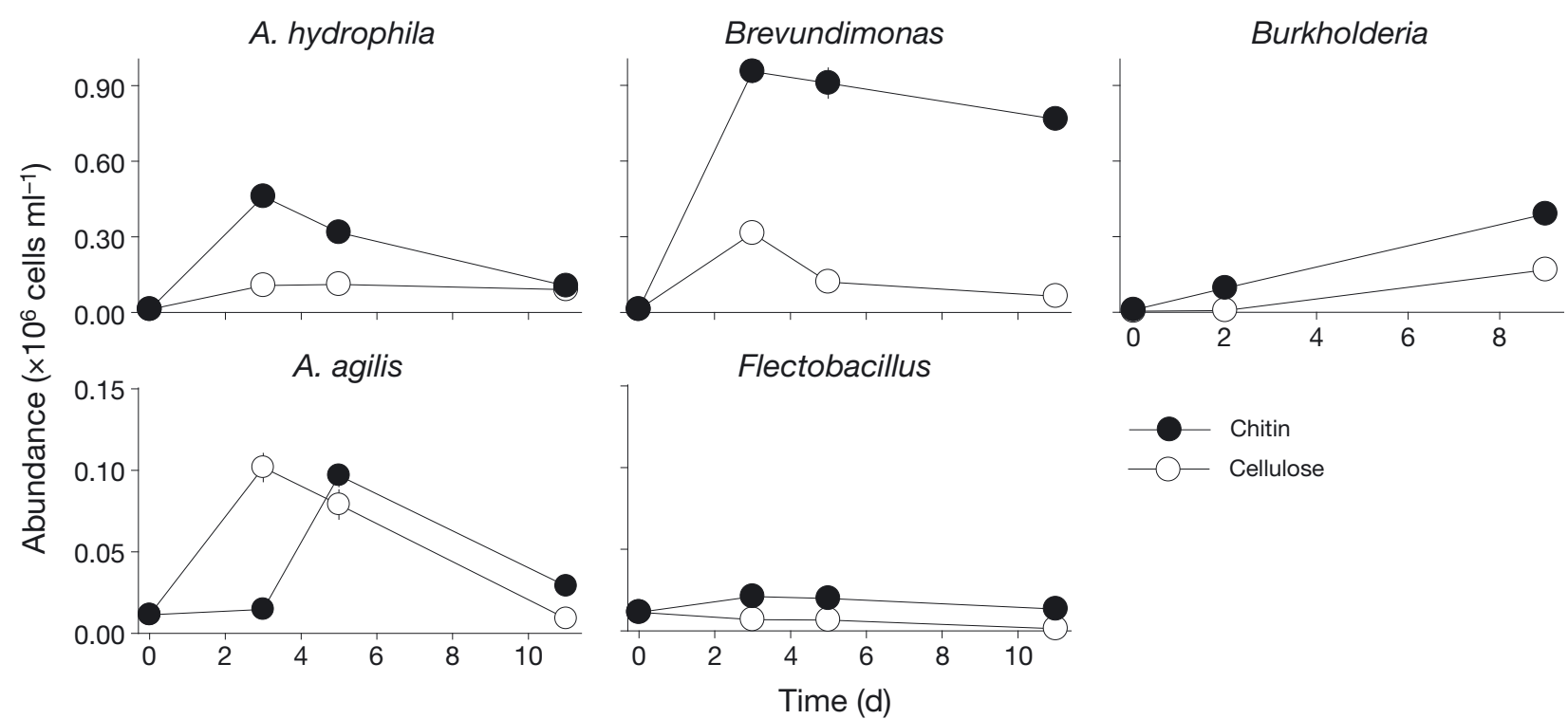

Fig. 1. Temporal changes in abundance of Aeromonas hydrophila, Brevundimonas, Burkholderia, Arthrobacter agilis and Flectobacillus grown in pure cultures either on chitin or cellulose. Values are means of triplicates; error bars: SD 


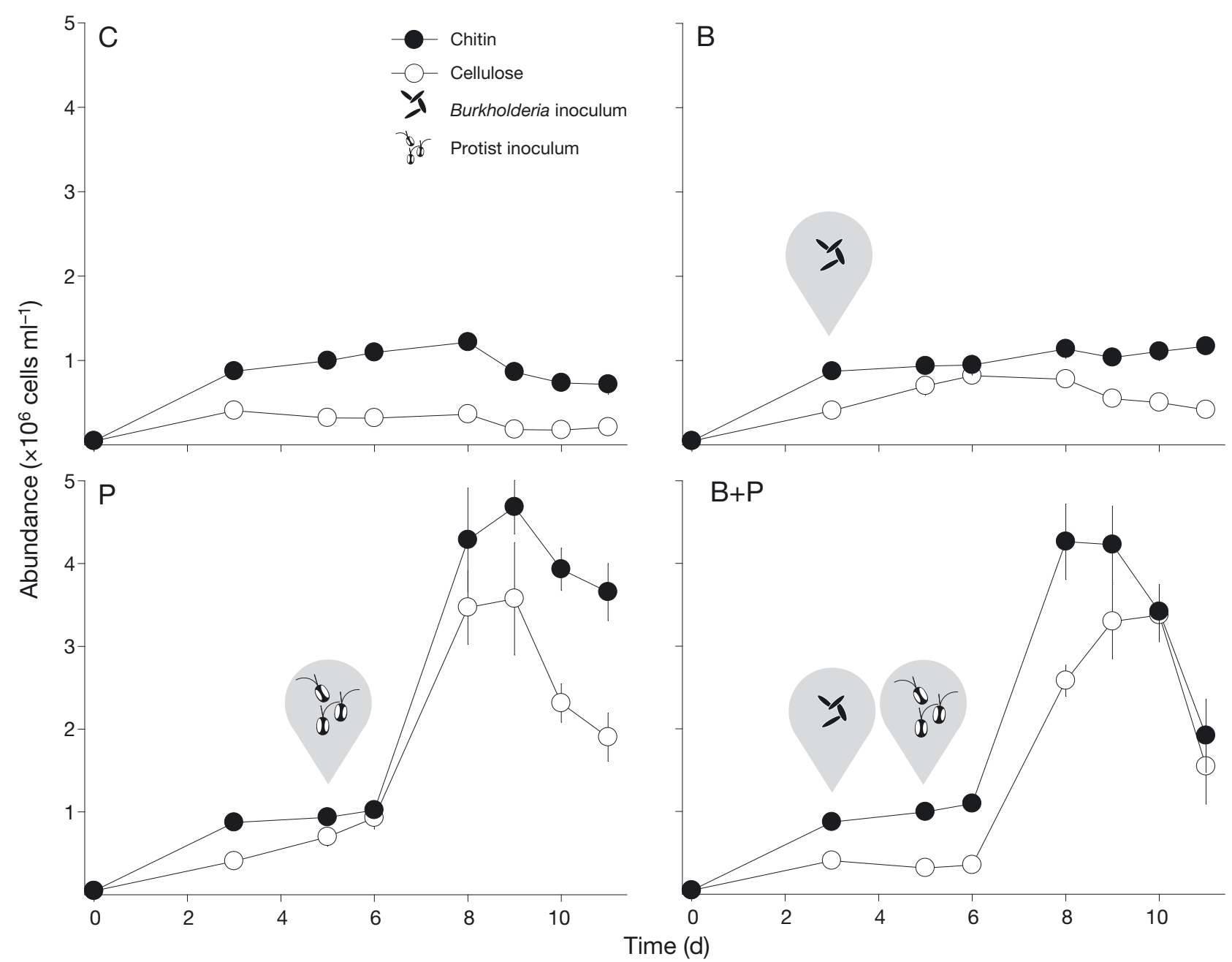

Fig. 2. Temporal changes in abundance of the bacterial community grown in control treatments (C), in treatments inoculated on Day 3 with Burkholderia (B), in treatments with the protist Poterioochromonas (P) inoculated on Day 5, or in treatments with both inocula (Burkholderia+Protists; B+P), either on chitin or cellulose (Days 6, 8, 9, 10, and 11). Values are means of triplicates; error bars: SD

was introduced on Day 5, reaching $4.68 \times 10^{6}$ cells $\mathrm{ml}^{-1}$ on chitin and $3.58 \times 10^{6}$ cells ml ${ }^{-1}$ on cellulose by Day 9. Thus, bacterial abundance after Day 5 was on average higher in grazed (Protist) than non-grazed (Control) communities $\left(\chi^{2}=32.32, \mathrm{df}=1, \mathrm{p}<0.0001\right)$, although bacterial density decreased from Days 9 to 11 in the Protist treatment. The increased bacterial abundance in the Protist treatment was specific to mixed communities: it was not observed in pure cultures of the component species (Fig. S2 in the Supplement). Despite this, addition of the protist did not induce qualitative changes in bacterial community composition: A. hydrophila and Brevundimonas consistently dominated, with a combined proportion always above $80 \%$ (Fig. 3). Addition of Burkholderia ('B' in Fig. 2), which reached frequencies of up to $16 \%$ of the total bacterial population, also increased the average total bacterial abundance after it was added on Day 3 (compared to Control treatment: $\chi^{2}=$ 11.07, $\mathrm{df}=1, \mathrm{p}=0.001$ ). This effect was much weaker than that of the protist and was stronger in cellulose than chitin (carbon source $\times$ Burkholderia interaction: $\left.\chi^{2}=27.09, \mathrm{df}=1, \mathrm{p}<0.0001\right)$. Changes in bacterial abundance in the Burkholderia+Protist treatment $\left({ }^{\prime} \mathrm{B}+\mathrm{P}^{\prime}\right.$ in Fig. 2) were similar to those in the Protist treatment, being on average significantly higher than in the Control treatment after Day $5\left(\chi^{2}=27.92\right.$, $\mathrm{df}=1, \mathrm{p}<0.0001$ ).

To determine whether the positive effects of the protist on total bacterial growth were due to exploitation of cellulose or chitin by the protist itself (which could increase the availability of metabolic by-products for bacterial growth), we measured growth of the protist in the absence of bacteria in chitin and cel- 


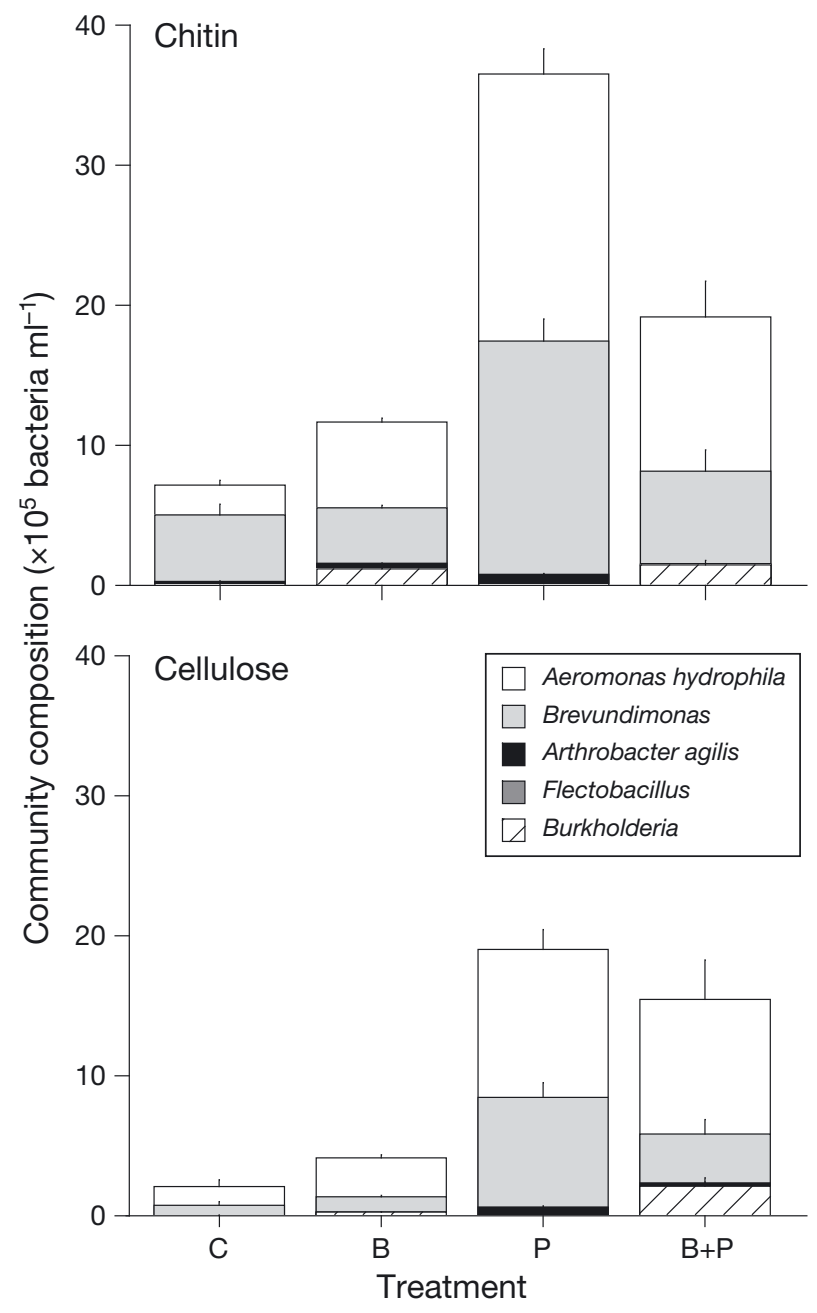

Fig. 3. Bacterial community composition at the end of the experiment (Day 11) in the different treatments (C: Control; B: Burkholderia; P: Protists; B+P: Burkholderia+Protists). Flectobacillus is not visible as their proportion was very low and they quickly ran to extinction. Error bars: SD

lulose growth medium. These experiments showed that Poterioochromonas does not grow in the absence of bacteria (Fig. S3). Therefore, it very probably grazes planktonic bacterial cells (Rothhaupt 1997), even though its presence had a net effect of increasing total bacterial abundance in mixed communities.

\section{Induced morphotype formation}

We detected 3 main bacterial morphotypes: (1) single free-living cells, (2) microcolonies (generally composed of a single strain) of 3 to 10 cells, and (3) large aggregates (generally composed of more than 1 species) of up to a few hundred cells. On both substrates, the proportion of cells in microcolonies accounted for $\sim 15 \%$ without and 20 to $25 \%$ with the protist (Fig. 4). The fraction of bacteria in aggregates at the end of the experiment varied depending on addition of the protist and Burkholderia (effect of treatment: $\chi^{2}=$ 79.64, df $=3, \mathrm{p}<0.0001$ ). Specifically, without the protist large aggregates were absent in cellulose, whereas in chitin $4 \%$ of the total bacterial population were present in aggregates. Addition of the protist significantly increased the incidence of aggregates, which accounted for almost $20 \%$ of the total bacterial population in both chitin and cellulose (Fig. 4), such that the fraction of aggregated cells was higher in both Protist and Burkholderia+Protist treatments

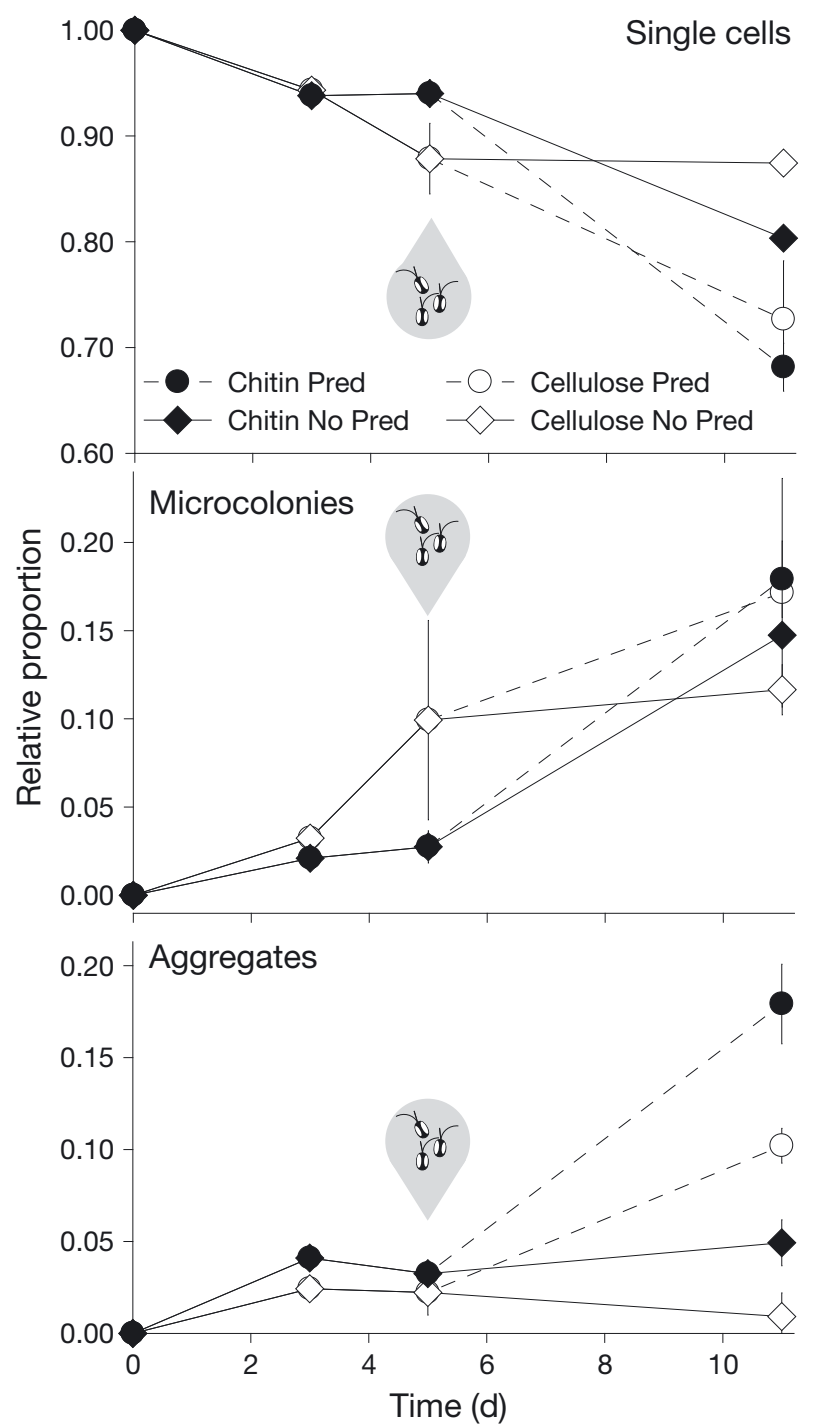

Fig. 4. Proportion of bacteria in each morphotype class with and without protists. Values are means of Control and Burkholderia treatment triplicates (without protists), and of Protist and Burkholderia+Protist treatments (with protists). Error bars: SD 
compared to the Control $(\mathrm{p}<0.0001$ in pairwise comparisons; Fig. 4). The proportion of cells in each morphotype class also varied among bacterial species (Fig. S4), with A. hydrophila, A. agilis and Burkholderia being particularly prone to aggregation.

\section{Carbon flux}

At the end of the experiment, the total amount of $\mathrm{C}$ stored in bacterial biomass was higher in the Burkholderia, Protist and Burkholderia+Protist treatments compared to the Control (Fig. 5). Note that in chitin cultures containing the protist, a significant fraction of additional $\mathrm{C}$ was stored in protist biomass. In cellulose cultures, even more $\mathrm{C}$ was stored in protists than in bacterial biomass. A schematic description of the C-flow on chitin and cellulose is given in Fig. 6.

\section{DISCUSSION}

Our results show that interactions among microbial species from different trophic levels play a fundamental role in bacterial exploitation of hardto-degrade, complex biopolymers. Addition of a protist grazer to a simplified community of 4 bacterial species caused a marked increase in total bacterial abundance (Fig. 2) that was associated with formation of multispecies aggregates and an increase in total C-transfer of the entire community. These findings are particularly relevant to microbial metabolism of $\mathrm{C}$ in nature for 2 reasons. First, the Csources in our experiments (chitin and cellulose) both constitute a large fraction of available $\mathrm{C}$ in natural aquatic environments (Gooday 1990, Hopkinson \& Vallino 2005). Second, aggregation of bacterial species in response to protist grazing has been observed in several other bacteria-protist combinations and experimental conditions (Grossart et al. 2006): anti-predation

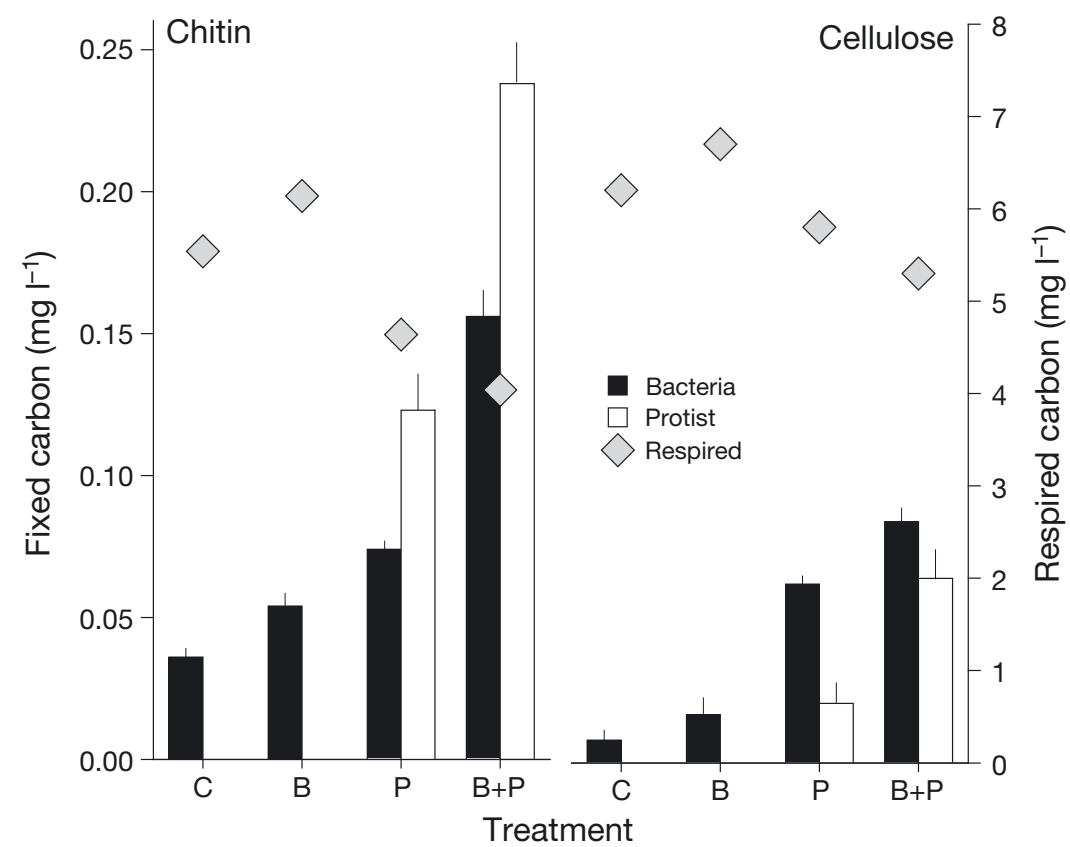

Fig. 5. Estimated proportions of particulate organic carbon bound in bacteria and flagellates at the end of the experiment (Day 11), on either chitin or cellulose. Diamonds: amount of organic carbon respired during the entire experiment

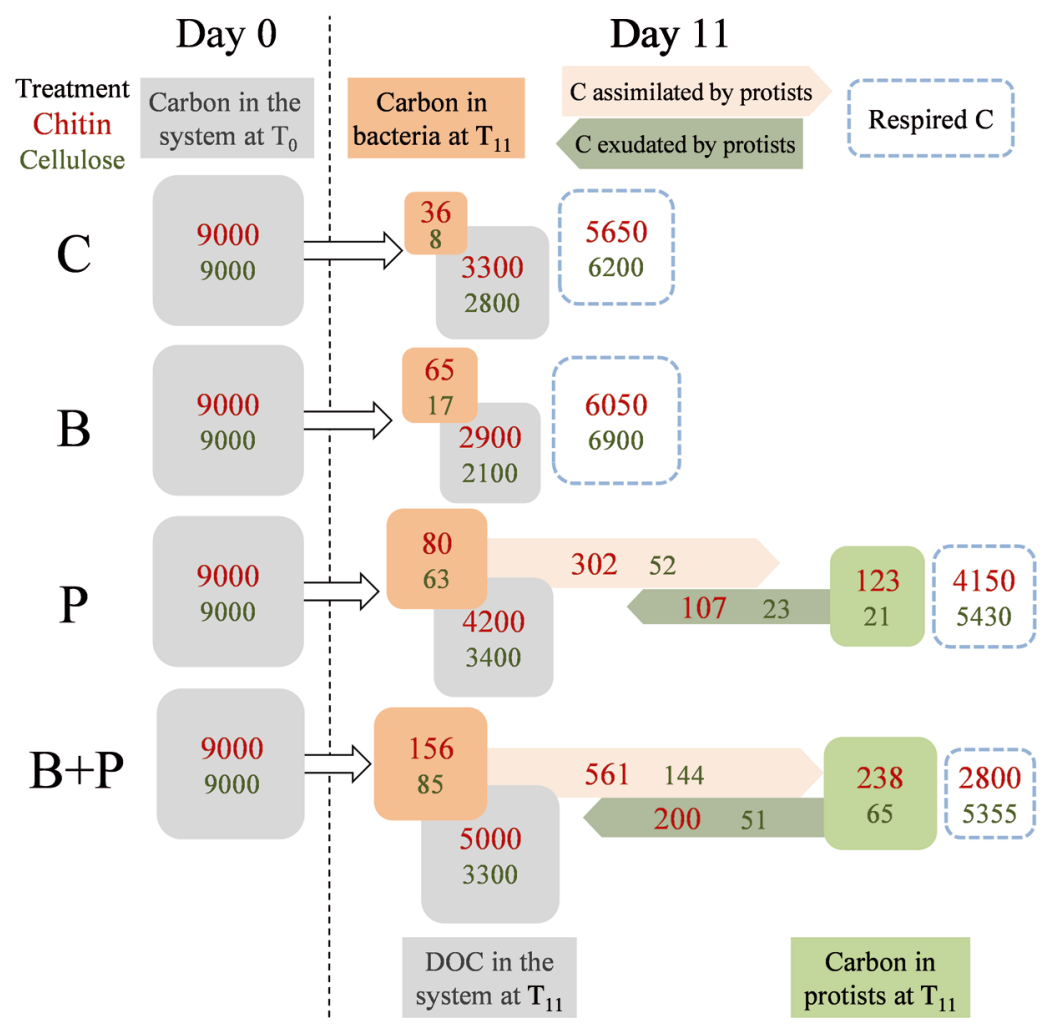

Fig. 6. Graphical and empirical modelling of the carbon fluxes. Fluxes (in mg $\mathrm{l}^{-1}$ ) are considered within the 4 treatments when grown on chitin (values in red) or cellulose (values in green). Data are directly measured (total dissolved $[\mathrm{DOC}]$ and particulate organic carbon [POC]), extrapolated (respired C) or estimated by the mathematical/empirical models (see 'Materials and methods') 
strategies such as formation of biofilms or microcolonies minimize the impact of flagellate predation (Matz \& Kjelleberg 2005), although they can incur energetic costs ('defence cost' paradigm; Coustau et al. 2000), limiting the ecological success of grazingresistant strains, and can be complicated by interactions with other organisms and viruses (Våge et al. 2014).

A number of ecological and physiological factors, as well as emerging interspecific interactions, may promote DOC-uptake efficiency and hence productivity in the presence of microcolonies and aggregates (Jousset et al. 2011, Lindström \& Östman 2011). Furthermore, indirect effects of protozoan grazing including the release of chemical cues (e.g. allelochemicals; Corno \& Jürgens 2006, Blom \& Pernthaler 2010), and the accumulation of leftovers from digested bacterial cells (Pernthaler et al. 1997) could potentially promote growth of bacterial cells of the same species that are not preyed upon-especially in systems with limited labile C (as in our experimental system).

The presence of protists has been shown to selectively promote the bacterial degradation of organic detritus with low mineral content (Sherr et al. 1982), again, supporting the hypothesis of a positive effect of grazing on total bacterial productivity. The increased C-transfer in to microbial biomass in our Protist treatment, where bacterial aggregation was more common, is consistent with evidence that bacteria in microcolonies or aggregates are more efficient in DOC-uptake and express a higher cell-specific production than free-living cells (Griffith et al. 1994, Grossart et al. 2003, 2007). This may reflect a general difference between diffusion-limitation of access to $\mathrm{C}$-sources in free-living and aggregated cells (Guasto et al. 2012). However, in scenarios where aggregation results from interaction with a protist grazer, as in our experiments, increased productivity may also reflect the growth-promoting effects of the metabolic by-products of protist growth (flagellates such as Poterioochromonas excrete ca. 30 to $40 \%$ of ingested C as labile DOC; Pelegrí et al. 1999), as well as C-transfer to the protist in the form of grazed cells. This is particularly relevant for spatially structured microenvironments such as microcolonies and aggregates (Hagström et al. 1988) where bacteria reach high densities and physiological coupling between microorganisms is likely, e.g. by releasing oxygen radicals (Diaz et al. 2013). Therefore, predation might have a strong impact not only on the composition of bacterial communities but also on their C-transfer efficiency.
Although the chemical structures of chitin and cellulose are homologous, their degradation rates in aquatic bacterial communities are different. Our data showed faster and more efficient degradation of chitin, confirming the results in similar systems observed on a different bacterial community by Peter et al. (2011). As in that study, we cannot exclude the fact that the observed better growth on chitin was promoted by the specific ability for chitin degradation of some of the strains in the community. At the same time, however, we suggest a possibly easier access of simplified bacterial communities to chitin than to other structurally heterogeneous polymers (e.g. cellulose).

Our experimental community included at least 2 strains belonging to genera that are recognized for their potential to degrade chitin and cellulose: cellulolytic activity has recently been attributed to a number of Burkholderia strains (Liang et al. 2014), and Burkholderia gladioli and Aeromonas sp. Strain 10S24 show chitinolytic activity (Kong et al. 2001, Ueda et al. 2003). The evaluation and comparison of growth curves, as well as of the community compositions between treatments, does not support the hypothesis of a direct competitive advantage for Burkholderia. It never exceeded 10 to $16 \%$ of the total number of bacteria, while Aeromonas was the most abundant strain in every treatment except for the chitin control.

Microbial metabolism of chitin and cellulose is inherently important because (1) they are both highly abundant in nature (Kaplan \& Newbold 2003, Beier \& Bertilsson 2011, Eckert et al. 2012), (2) relatively few bacteria (1 to $5 \%$ of the total bacterial communities in coastal and freshwaters; Cottrell et al. 1999, Beier \& Bertilsson 2011) are capable of exploiting such complex biopolymers, but (3) many bacteria utilize substrates that result from chitin or cellulose degradation (up to $40 \%$ of the total bacterial communities; Nedoma et al. 1994, Riemann \& Azam 2002). Overall, the estimated amount of chitin degraded per day in coastal, estuarine or freshwater systems varies between 2 and $30 \%$ of the total pool, while in open seas this proportion is $<1 \%$ (Gooday et al. 1991, Boyer 1994). Based on this finding, we propose that bacteria in microcolonies and on aggregates (with a relatively lower proportion in the open ocean than in coastal, estuary or freshwater ecosystems) form closely coupled meta-communities, enabling a potentially more efficient community metabolism (Fig. 6) than the suspended, free-living cells. In coastal and inland waters, ca. 20 to $30 \%$ of all bacteria occur on biofilms attached to particles and on aggregates (as estimated from data in Maranger \& Bird 1995, Whitman et al. 
1998, Amaral-Zettler et al. 2010), and although not necessarily chitinolytic or cellulolytic (as in our study), their potential to degrade cellulose and chitin increases by 5 - and 10-fold in aggregates. Bacteria occurring on aggregates could thus account for almost 60 and $75 \%$ of cellulose and chitin degradation by bacteria in coastal and inland waters, respectively.

In conclusion, protist grazing of bacteria resulted in aggregate formation, and this in turn strongly influenced total bacterial population density and increased community-level metabolism of chitin and cellulose. This suggests that interspecific microbial interactions (Nobu et al. 2015) are of fundamental importance to understanding $\mathrm{C}$-cycling in aquatic environments at a global scale. Thus, altering microbial interactions at the microscale (i.e. in microcolonies and on aggregates) has far-reaching implications for organic matter and C-cycling on earth. Yet it remains unknown how anthropogenic activities (e.g. input of nutrients, toxins, and microplastics) affect microbial interactions in the microscale, and what the ultimate consequences for earth's biochemistry may be.

Acknowledgements. We thank F. Bulleri, D. Fontaneto, and E. Eckert for suggestions on the experimental modelling, E. Eckert for design and production of graphs, and S. Pinnow for operation of the flow cytometer. Poterioochromonas was provided by J. Blom (University of Zürich). This study was partially funded by the Short-Term Mobility programme 2014 of the National Research Council of Italy. The authors declare no conflict of interest.

\section{LITERATURE CITED}

Amaral-Zettler L, Artigas LF, Baross J, Bharathi L and others (2010) A global census of marine microbes. In: McIntyre A (ed) Life in the world's oceans: diversity, distribution and abundance. Blackwell Publishing, Oxford, p 223-245

Beier S, Bertilsson S (2011) Uncoupling of chitinase activity and uptake of hydrolysis products in freshwater bacterioplankton. Limnol Oceanogr 56:1179-1188

Blom JF, Pernthaler J (2010) Antibiotic effects of three strains of chrysophytes (Ochromonas, Poterioochromonas) on freshwater bacterial isolates. FEMS Microbiol Ecol 71:281-290

Borsodi AK, Micsinai A, Rusznyak A, Vladar P, Kovacs G, Toth EM, Marialigeti K (2005) Diversity of alkaliphilic and alkalitolerant bacteria cultivated from decomposing reed rhizomes in a Hungarian soda lake. Microb Ecol 50: 9-18

Boyer JN (1994) Aerobic and anaerobic degradation and mineralization of ${ }^{14} \mathrm{C}$-chitin by water column and sediment inocula of the York River estuary, Virginia. Appl Environ Microbiol 60:174-179

Callieri C, Corno G, Bertoni R (2006) Bacterial grazing by mixotrophic flagellates and Daphnia longispina: a com- parison in a fishless alpine lake. Aquat Microb Ecol 42: 127-137

Cardenas E, Wu WM, Leigh MB, Carley J and others (2008) Microbial communities in contaminated sediments, associated with bioremediation of uranium to submicromolar levels. Appl Environ Microbiol 74:3718-3729

> Corno G (2006) Effects of nutrient availability and Ochromonas sp. predation on size and composition of a simplified aquatic bacterial community. FEMS Microbiol Ecol 58:354-363

Corno G, Jürgens K (2006) Direct and indirect effects of protist predation on population size structure of a bacterial strain with high phenotypic plasticity. Appl Environ Microbiol 72:78-86

Corno G, Jürgens K (2008) Structural and functional patterns of bacterial communities in response to protist predation along an experimental productivity gradient. Environ Microbiol 10:2857-2871

Corno G, Caravati E, Callieri C, Bertoni R (2008) Effects of predation pressure on bacterial abundance, diversity, and size-structure distribution in an oligotrophic system. J Limnol 67:107-119

> Corno G, Villiger J, Pernthaler J (2013) Coaggregation in a microbial predator-prey system affects competition and trophic transfer efficiency. Ecology 94:870-881

Cottrell MT, Moore JA, Kirchman DL (1999) Chitinases from uncultured marine microorganisms. Appl Environ Microbiol 65:2553-2557

Coustau C, Chevillon C, Ffrench-Constant R (2000) Resistance to xenobiotics and parasites: Can we count the cost? Trends Ecol Evol 15:378-383

Crawley MJ (2007) The R book. John Wiley \& Sons, Chichester

del Giorgio PA, Newell REI (2012) Phosphorus and DOC availability influence the partitioning between bacterioplankton production and respiration in tidal marsh ecosystems. Environ Microbiol 14:1296-1307

> del Giorgio PA, Condon R, Bouvier T, Longnecker K and others (2011) Coherent patterns in bacterial growth, growth efficiency, and leucine metabolism along a northeastern Pacific inshore-offshore transect. Limnol Oceanogr 56:1-16

- Diaz JM, Hansel CM, Voelker BM, Mendes CM, Andeer PF, Zhang T (2013) Widespread production of extracellular superoxide by heterotrophic bacteria. Science 340: 1223-1226

Eckert EM, Salcher MM, Posch T, Eugster B, Pernthaler J (2012) Rapid successions affect microbial N-acetylglucosamine uptake patterns during a lacustrine spring phytoplankton bloom. Environ Microbiol 14:794-806

Gasol JM, Zweifel UL, Peters F, Fuhrman JA, Hagström A (1999) Significance of size and nucleic acid content heterogeneity as measured by flow cytometry in natural planktonic bacteria. Appl Environ Microbiol 65: 4475-4483

Gooday GW (1990) The ecology of chitin degradation. In: Marshall KC (ed) Advances in microbial ecology. Plenum Press, New York, NY, p 387-430

Gooday GW, Prosser JI, Hillman K, Cross MG (1991) Mineralization of chitin in an estuarine sediment: the importance of the chitosan pathway. Biochem Syst Ecol 19: 395-400

Griffith P, Shiah FK, Gloersen K, Ducklow HK, Fletcher M (1994) Activity and distribution of attached bacteria in Chesapeake Bay. Mar Ecol Prog Ser 108:1-10 
Grossart HP, Hietanen S, Ploug H (2003) Microbial dynamics on diatom aggregates in Oresund, Denmark. Mar Ecol Prog Ser 249:69-78

Grossart HP, Kiorbøe T, Tang KW, Allgaier M, Yam EM, Ploug $H$ (2006) Interactions between marine snow and heterotrophic bacteria: aggregate formation and microbial dynamics. Aquat Microb Ecol 42:19-26

> Grossart HP, Tang KW, Kiørboe T, Ploug H (2007) Comparison of cell-specific activity between free-living and attached bacteria using isolates and natural assemblages. FEMS Microbiol Lett 266:194-200

Guasto JS, Rusconi R, Stocker R (2012) Fluid mechanics of planktonic microorganisms. Annu Rev Fluid Mech 44: $373-400$

> Hagström A, Azam F, Andersson A, Wikner J, Rassoulzadegan F (1988) Microbial loop in an oligotrophic pelagic marine ecosystem: possible roles of cyanobacteria and nanoflagellates in the organic fluxes. Mar Ecol Prog Ser 49:171-178

> Hahn MW, Scheuerl T, Jezberová J, Koll U and others (2012) The passive yet successful way of planktonic life: genomic and experimental analysis of the ecology of a free-living Polynucleobacter population. PLoS ONE 7: e32772

Hiibel SR, Pereyra LP, Inman LY, Tischer A, Reisman DJ, Reardon KF, Pruden A (2008) Microbial community analysis of two field-scale sulfate-reducing bioreactors treating mine drainage. Environ Microbiol 10:2087-2097

Hopkinson CS, Vallino JJ (2005) Efficient export of carbon to the deep ocean through dissolved organic matter. Nature 433:142-145

Horňák K, Corno G (2012) Every coin has a back side: invasion by Limnohabitans planktonicus promotes the maintenance of species diversity in bacterial communities. PLoS ONE 7:e51576

> Hutalle-Schmelzer KML, Zwirnmann E, Krüger A, Grossart HP (2010) Enrichment and cultivation of pelagic bacteria from a humic lake using phenol and humic matter additions. FEMS Microbiol Ecol 72:58-73

> Ibekwe AM, Grieve CM, Lyon SR (2003) Characterization of microbial communities and composition in constructed dairy wetland wastewater effluent. Appl Environ Microbiol 69:5060-5069

Jessup CM, Forde SE, Bohannan BJM (2005) Microbial experimental systems in ecology. Adv Ecol Res 37:273-307

> Jiao N, Herndl GJ, Hansell DA, Benner R and others (2010) Microbial production of recalcitrant dissolved organic matter: long-term carbon storage in the global ocean. Nat Rev Microbiol 8:593-599

> Jousset A, Schmid B, Scheu S, Eisenhauer N (2011) Genotypic richness and dissimilarity opposingly affect ecosystem functioning. Ecol Lett 14:537-545

Kaplan LA, Newbold JD (2003) The role of monomers in stream ecosystem metabolism. In: Finlay SEG, Sinsabaugh RL (eds) Aquatic ecosystems: interactivity of dissolved organic matter. Academic Press, San Diego, CA, p 97-119

Keller L, Surette MG (2006) Communication in bacteria: an ecological and evolutionary perspective. Nat Rev Microbiol 4:249-258

Kong H, Shimosaka M, Ando Y, Nishiyama K, Fujii T, Miyashita K (2001) Species-specific distribution of a modular family 19 chitinase gene in Burkholderia gladioli. FEMS Microbiol Ecol 37:135-141

Liang YL, Zhang Z, Wu M, Wu Y, Feng JX (2014) Isolation, screening, and identification of cellulolytic bacteria from natural reserves in the subtropical region of China and optimization of cellulase production by Paenibacillus terrae ME27-1. Biomed Res Int 2014:512497, doi:10.1155/ 2014/512497

Lindström ES, Östman Ö (2011) The importance of dispersal for bacterial community composition and functioning. PLoS ONE 6:e25883

Litchman E (2010) Invisible invaders: non-pathogenic invasive microbes in aquatic and terrestrial ecosystems. Ecol Lett 13:1560-1572

> Loferer-Krössbacher M, Klima J, Psenner R (1998) Determination of bacterial cell dry mass by transmission electron microscopy and densitometric image analysis. Appl Environ Microbiol 64:688-694

Maranger R, Bird DF (1995) Viral abundance in aquatic systems: a comparison between marine and fresh waters. Mar Ecol Prog Ser 121:217-226

> Matz C, Kjelleberg S (2005) Off the hook-how bacteria survive protozoan grazing. Trends Microbiol 13:302-307

Mayor DJ, Sanders R, Giering SLC, Anderson TR (2014) Microbial gardening in the ocean's twilight zone: detritivorous metazoans benefit from fragmenting, rather than ingesting, sinking detritus. BioEssays 36:1132-1137

McInerney MJ, Struchtemeyer CG, Sieber J, Mouttaki H and others (2008) Physiology, ecology, phylogeny, and genomics of microorganisms capable of syntrophic metabolism. Ann NY Acad Sci 1125:58-72

Menden-Deuer S, Lessard EJ, Satterberg J (2001) Effect of preservation on dinoflagellate and diatom cell volume and consequences for carbon biomass predictions. Mar Ecol Prog Ser 222:41-50

> Miki T, Yokokawa T, Matsui K (2014) Biodiversity and multifunctionality in a microbial community: a novel theoretical approach to quantify functional redundancy. Proc R Soc B 281:20132498

- Nedoma J, Vrba J, Hejzlar J, Šimek K, Straškrabová V (1994) N-acetylglucosamine dynamics in 434 freshwater environments: concentration of amino sugars, extracellular enzyme activities, and microbial 435 uptake. Limnol Oceanogr 39:1088-1100

- Nobu MK, Narihiro T, Rinke C, Kamagata Y, Tringe SG, Woyke T, Liu WT (2015) Microbial dark matter ecogenomics reveals complex synergistic networks in a methanogenic bioreactor. ISME J 9:1710-1722

Pelegrí SP, Christaki U, Dolan J, Rassoulzadegan F (1999) Particulate and dissolved organic carbon production by the heterotrophic nanoflagellate Pteridomonas danica Patterson and Fenchel. Microb Ecol 37:276-284

Pernthaler J, Posch T, Šimek K, Vrba J, Amann R, Psenner R (1997) Contrasting bacterial strategies to coexist with a flagellate predator in an experimental microbial assemblage. Appl Environ Microbiol 63:596-601

Peter H, Beier S, Bertilsson S, Lindström ES, Langenheder S, Tranvik LJ (2011) Function-specific response to depletion of microbial diversity. ISME J 5:351-361

R Development Core Team (2013) R: a language and environment for statistical computing. R Foundation for Statistical Computing, Vienna

> Riemann L, Azam F (2002) Widespread N-acetyl-D-glucosamine uptake among pelagic marine bacteria and its ecological implications. Appl Environ Microbiol 68: 5554-5562

> Rothhaupt KO (1997) Nutrient turnover by freshwater bacterivorous flagellates: differences between a heterotro- 
phic and a mixotrophic chrysophyte. Aquat Microb Ecol 12:65-70

Sherr BF, Sherr E, Berman T (1982) Decomposition of organic detritus: a selective role for microflagellate protozoa. Limnol Oceanogr 27:765-769

Sinsabaugh RL, Findlay SEG (2003) Dissolved organic matter: out of the black box into the mainstream. In: Findlay SEG, Sinsabaugh RL (eds) Aquatic ecosystems: interactivity of dissolved organic matter. Academic Press, San Diego, CA, p 479-498

Ueda M, Kojima M, Yoshikawa T, Mitsuda N and others (2003) A novel type of family 19 chitinase from Aeromonas sp. No.10S-24. Cloning, sequence, expression, and the enzymatic properties. Eur J Biochem 270: 2513-2520

Editorial responsibility: Paul del Giorgio, Montreal, Canada
Våge S, Storesund JE, Giske J, Thingstad TF (2014) Optimal defense strategies in an idealized microbial food web under trade-off between competition and defense. PLoS ONE 9:e101415

Venail PA, MacLean RC, Bouvier T, Brockhurst MA, Hochberg ME, Mouquet N (2008) Diversity and productivity peak at intermediate dispersal rate in evolving metacommunities. Nature 452:210-214

Whitman WB, Coleman DC, Wiebe WJ (1998) Prokaryotes: the unseen majority. Proc Natl Acad Sci USA 95: 6578-6583

Zotina T, Koster O, Juttner F (2003) Photoheterotrophy and light-dependent uptake of organic and organic nitrogenous compounds by Planktothrix rubescens under low irradiance. Freshw Biol 48:1859-1872

Submitted: February 9, 2015; June 29, 2015

Proofs received from author(s): August 11, 2015 